\title{
Prediksi Ketinggian Gelombang Laut Perairan Laut Jawa Bagian Barat Sebelah Utara Jakarta dengan Metode Jaringan Syaraf Tiruan Propagasi Balik

\author{
Prada Wellyantama1)
}

\author{
1 BMKG Stasiun Meteorologi Maritim Pontianak \\ *Email : prada_wellyantama@yahoo.com
}

\begin{abstract}
Abstrak
Telah dilakukan estimasi dan prediksi ketinggian gelombang perairan Laut Jawa bagian Barat sebelah Utara Jakarta menggunakan metode Jaringan Syaraf Tiruan Propagasi Balik. Data yang digunakan yaitu data ketinggian gelombang laut maksimum mingguan, dari tahun 2005 sampai dengan 2014. Jaringan Syaraf Tiruan (JST) yang digunakan adalah JST Propagasi Balik berarsitektur [40 3020 1] dengan distribusi lapisan yang terdiri dari 6 lapisan input, 4 lapisan tersembunyi, dan 1 lapisan output. Fungsi aktifasi yang digunakan adalah fungsi linear, sigmoid bipolar dan sigmoid biner. Dari hasil pengujian diperoleh nilai koefisien korelasi pengujian di lima titik penelitian masing-masing 0,78;0,70;0,72;0,74 dan 0,70. Hasil prediksi puncak gelombang maksimum terjadi pada minggu pertama November 2014, minggu pertama hingga keempat Desember 2014, minggu pertama Januari 2015, minggu keempat Maret 2015 dan minggu keempat April 2015.
\end{abstract}

Kata Kunci : Gelombang, Laut Jawa, JST, Propagasi Balik

\section{Pendahuluan}

Indonesia adalah negara maritim yang membentang luas di khatulistiwa dari $94^{0}$ sampai $141^{0}$ Bujur Timur dan $6^{0}$ Lintang Utara sampai $11^{0}$ Lintang Selatan dengan karakteristik negara kepulauan yang terdiri dari sekitar 17.508 pulau dan panjang garis pantai sekitar $81.000 \mathrm{~km}$ (Dahuri, 2004). Sebagai negara bahari dan maritim, perairan di Indonesia memiliki peran penting dalam berbagai aspek kehidupan. Demi menunjang kelancaran pemanfaatan p'erairan Indonesia di berbagai bidang tersebut banyak faktor yang harus diperhatikan oleh pengguna, seperti cuaca, kelayakan fasilitas (angkutan laut) dan lain sebagainya. Dalam hal ini pembahasan faktor cuaca khususnya ketinggian gelombang lebih diprioritaskan, ini dikarenakan kegiatan pelayaran membutuhkan waktu lebih lama di perjalanan dari kegiatan manusia lainnya, sehingga resiko selama perjalanan juga jauh lebih tinggi.

Ketinggian gelombang laut perairan Laut Jawa bagian Barat sebelah Utara Jakarta tersebut diprediksi dengan menggunakan metode jaringan syaraf tiruan propagasi balik. Jaringan syaraf tiruan (JST) adalah sistem pemrosesan informasi yang memiliki karakteristik mirip dengan jaringan syaraf biologi. Secara umum arsitektur JST terdiri dari masukan (input layer), lapisan tersembunyi (hidden layer) dan keluaran (output) (Agustin, 2012).

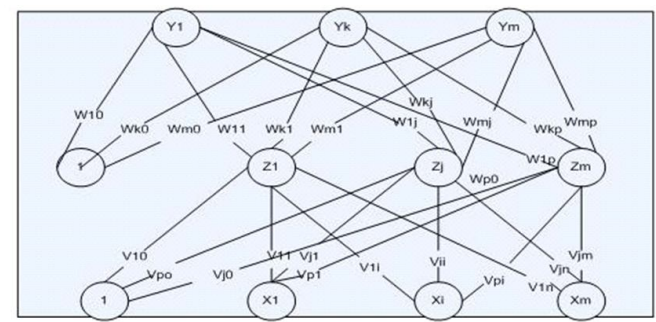

Gambar 1. Arsitektur JST (Siang, 2004)

Penelitian ini dilakukan di perairan Laut Jawa bagian Barat sebelah Utara Jakarta, serta data yang digunakan adalah data ketinggian gelombang maksimum. Pada penelitian sebelumnya oleh Kresnawan (2009), prediksi ketinggian gelombang laut dilakukan dengan data masukan sekaligus prediktor berupa data temperatur, tekanan, kelembaban udara dan kecepatan angin. Penelitian lainnya oleh Bekalani (2013) prediksi ketinggian gelombang dilakukan dengan menggunakan data gelombang signifikan. Sedangkan pada penelitian ini data masukan berupa data ketinggian gelombang maksimum dari tahun 2005 hingga Oktober 2014, gelombang maksimum digunakan agar segala kemungkinan kejadian ekstrim dapat diprediksi.

\section{Metodologi}

Data yang digunakan pada penelitian ini adalah data ketinggian gelombang maksimum mingguan perairan Laut Jawa bagian Barat sebelah Utara Jakarta dari tahun 2005-2014. Data tersebut diperoleh dari Stasiun Meteorologi Maritim Pontianak yang terdiri dari lima titik koordinat yang tertera pada Tabel 1. 
Tabel 1. Koordinat data ketinggian gelombang

\begin{tabular}{c|c}
\hline Bujur Timur & Lintang Selatan \\
\hline 106,5 & 4,5 \\
106,5 & 5,5 \\
107,0 & 5,0 \\
107,5 & 4,5 \\
107,5 & 5,5 \\
\hline
\end{tabular}

(sumber : www.maritim.bmkg.go.id)

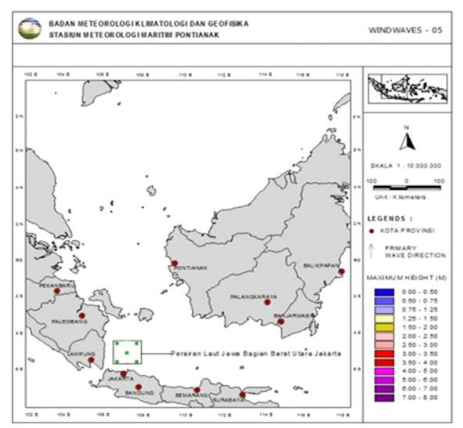

Gambar 2. Peta koordinat data penelitian (www.maritim.bmkg.go.id)

Dalam penelitian Prediksi Ketinggian gelombang dengan JST digunakan 5 langkah :

1. Memisahkan data yang akan digunakan sebagai data pelatihan dan data pengujian. Data ketinggian gelombang perairan Laut Jawa bagian Barat sebelah Utara Jakarta dari tahun 2005 hingga Desember 2010 akan digunakan sebagai data pelatihan sedangkan data dari bulan September 2010 hingga Oktober 2014 digunakan sebagai data uji.

2. Desain JST

Desain JST dilakukan untuk memprediksi ketinggian gelombang mingguan, dimulai dengan menentukan banyaknya data masukan yang digunakan dalam pelatihan, banyaknya lapisan tersembunyi yang digunakan dan banyaknya keluaran yang diinginkan. Data yang digunakan sebagai masukan dalam pelatihan sebanyak 264 data (264 minggu) pada masing-masing koordinat yakni dari Januari 2005 hingga Desember 2010 dan data target sebanyak 144 data. Sedangkan data pengujian digunakan data ketinggian gelombang maksimum mingguan dari Januari 2011 hingga Oktober 2014 untuk memprediksi ketinggian gelombang pada tahun 2014 hingga 2015.

3. Pengenalan pola (pelatihan)

Selama propagasi maju, sinyal masukan (xi) dipropagasikan ke lapisan tersembunyi menggunakan fungsi aktivasi yang ditentukan sebelumnya. Keluaran dari setiap unit lapisan tersembunyi (zj) tersebut selanjutnya dipropagasi majukan lagi ke lapisan tersembunyi di atasnya menggunakan fungsi aktivasi yang telah ditentukan. Demikian seterusnya hingga menghasilkan keluaran jaringan (yk). Pelatihan akan selesai apabila selisih antara target (tk) dan keluaran jaringan (yk) menghasilkan nilai kurang dari 0,17. Error dihitung setelah tahapan forward propagation (Propagasi Maju). Apabila error lebih besar dari nilai error maksimal $(0,17)$ maka pelatihan akan dilanjutkan ke tahap backward propagation (propagasi Balik), dimana bobot setiap garis dalam jaringan akan dimodifikasi untuk mengurangi kesalahan yang terjadi. Pengenalan pola diperlukan untuk melakukan penyesuain nilai bobot dengan nilai target (keluaran) yang diinginkan sehingga akan menghasilkan bobot optimal yang bisa mengenali data uji. Pengenalan pola data ketinggian gelombang adalah dengan melakukan pelatihan dengan menggunakan set data untuk pelatihan. Proses pelatihan menggunakan 288 data ketinggian gelombang dan 184 data ketinggian gelombang untuk data pengujian. Hasil pengujian tersebut akan digunakan sebagai estimasi. Data masukan sistem dari jaringan adalah ketinggian gelombang pada minggu ke-1 hingga minggu ke-264 sedangkan target sistem adalah ketinggian gelombang pada minggu ke-145 hingga minggu ke-288. Jaringan syaraf ini terdiri atas 6 lapisan input, 4 lapisan tersembunyi, dan 1 lapisan target. Lapisan tersembunyi pertama terdiri atas 40 neuron dengan fungsi aktifasi sigmoid bipolar. Lapisan tersembunyi kedua terdiri atas 30 neuron dengan fungsi aktifasi sigmoid bipolar. Lapisan tersembunyi ketiga terdiri atas 20 neuron dengan fungsi aktifasi sigmoid bipolar. Lapisan tersembunyi keempat terdiri atas 1 neuron fungsi aktivasi linear.

4. Pengujian dan Estimasi

Pengujian data yang dilakukan bertujuan untuk mengetahui apakah jaringan mampu mengenali pola data pelatihan dari data masukan yang diberikan. Apabila nilai error yang dihasilkan sudah mencapai target, maka keluaran yang dihasilkan dapat digunakan sebagai data estimasi. Nilai validasi model didapat dari koefisien korelasi (r) dimana Nilai $r$ terbesar adalah +1 dan $r$ terkecil adalah $0, r=+1$ menunjukan hubungan positif sempurna, sedangkan $r=-1$ menunjukan hubungan negatif sempurna. Nilai koefisien korelasi ( $r$ ) tidak mempunyai 
satuan atau dimensi. Tanda + atau - hanya menunjukan arah hubungan (Solihati, 2011). Interpretasi nilai $r$ adalah sebagai berikut:

Tabel 2. Hubungan koefisien korelasi dengan interpretasi

\begin{tabular}{cc}
\hline Interval Koefisien & Tingkat Hubungan \\
\hline $0,00-0,20$ & Sangat Rendah \\
$0,20-0,39$ & Rendah \\
$0,40-0,59$ & Sedang \\
$0,60-0,79$ & Tinggi \\
$0,80-1,00$ & Sangat Tinggi
\end{tabular}

(sumber : Sugiyono, 2008)

Pengujian dan estimasi dilakukan setelah proses pengenalan pola dalam pelatihan selesai.

5. Prediksi

Dengan propagasi balik, record data dipakai sebagai data pelatihan untuk mencari bobot yang optimal. Dengan keoptimalan bobot data yang didapat tersebut tentunya akan semakin meningkatkan kualitas dari nilai prediksi yang akan dicari.

\section{Hasil dan Pembahasan}

1. Titik Koordinat 106,5 BT; 4,5 LS

Pada titik koordinat pertama 106,5 BT; 4,5 LS pelatihan dilakukan berulang hingga jumlah siklus tertentu yang akan dihentikan jika MSE (Mean Square Error) mencapai 0,17. Hasil evaluasi data pelatihan didapatkan koefisien korelasi sebesar 0,91, hal ini menunjukkan hubungan yang sangat tinggi antara data keluaran terhadap data target. Sedangkan pada proses pengujian dengan data uji yakni data dari tahun 2011-2014 didapatkan korelasi sebesar 0,78 atau dalam kategori yang tinggi untuk diteruskan ke dalam proses prediksi.

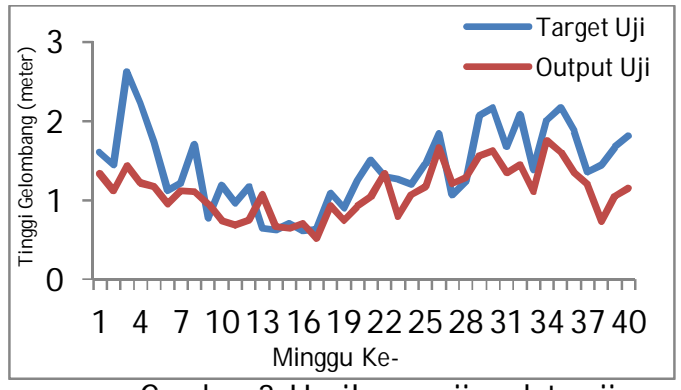

Gambar 3. Hasil pengujian data uji

Kategori tinggi tersebut ditunjukkan dengan data keluaran (output) dan target yang keduanya menunjukkan pola yang sangat mendekati seperti terlihat pada Gambar 3.

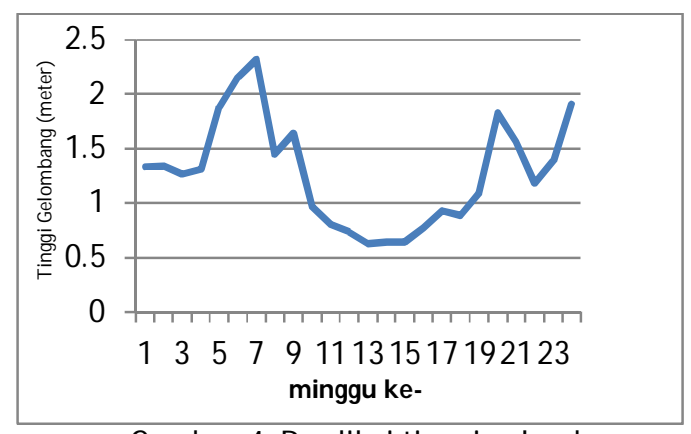

Gambar 4. Prediksi tinggi gelombang

Dari hasil prediksi didapatkan ketinggian gelombang maksimum pada koordinat 106,5 BT; 6,5 LS seperti pada Gambar 4, nilai tertinggi terjadi pada minggu ke-3 Desember 2014 dan nilai terendah terjadi pada minggu pertama Februari 2015.

\section{Titik Koordinat 106,5 BT; 5,5 LS}

Pada titik koordinat kedua 106,5 BT; 5,5 LS pelatihan dilakukan dengan MSE yang ditentukan sebesar 0,17. Dalam proses pelatihan didapatkan koefisien korelasi sebesar 0,92 antara data output dengan target atau dalam kategori sangat tinggi.

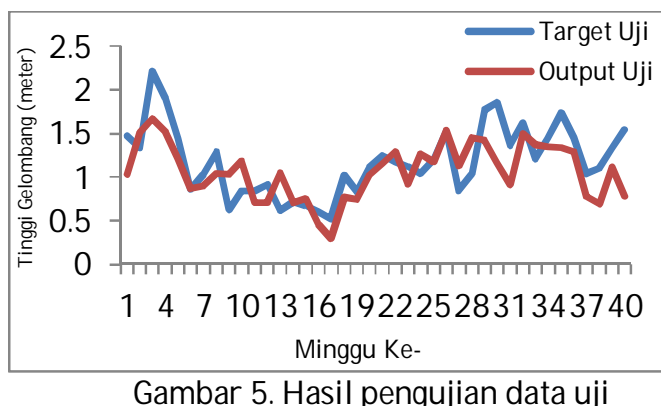

Gambar 5. menunjukkan pola yang sangat mendekati antara nilai keluaran dengan target dan didapatkan koefisien korelasi sebesar 0,71 atau kategori tinggi untuk diteruskan ke dalam proses prediksi.

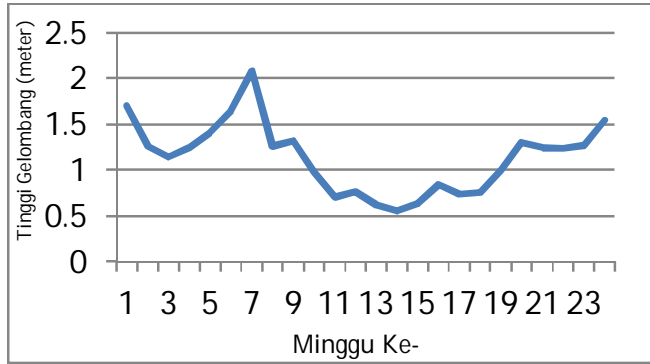

Gambar 6. Prediksi tinggi gelombang

Dari hasil prediksi sebagaimana pada Gambar 6, didapatkan puncak tertinggi 
ketinggian gelombang maksimum terjadi pada minggu ke-3 Desember 2014 dan terendah terjadi pada minggu ke-2 Februari 2015.

3. Titik Koordinat 107,0 BT; 5 LS

Pada titik koordinat ketiga 107,0 BT; 5 LS pelatihan juga dilakukan berulang dengan MSE yang ditentukan sebesar 0,71 dan pada proses pelatihan didapatkan koefisien korelasi sebesar 0,91 atau korelasi yang sangat tinggi dari data keluaran terhadap data target.

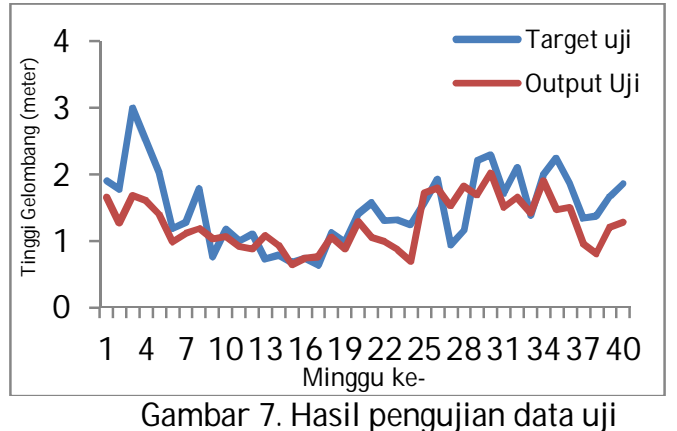

Setelah dilakukan pengujian didapatkan koefisien korelasi sebesar 0,72 atau dalam kategori yang tinggi untuk diteruskan ke dalam proses prediksi serta antara data keluaran dan data target menunjukkan pola yang sangat mendekati seperti yang terlihat pada Gambar 7.

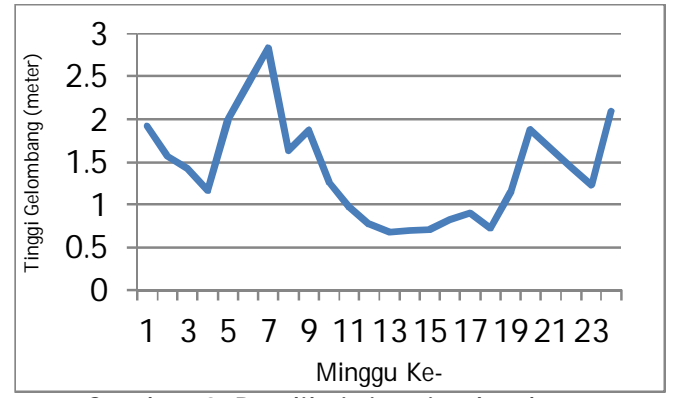

Gambar 8. Prediksi tinggi gelombang

Dari hasil prediksi didapatkan puncak tertinggi ketinggian gelombang maksimum terjadi pada mingu ke-3 Desember 2014 dan terendah terjadi pada minggu ke-2 Februari 2015, seperti yang terlihat pada Gambar 8.

\section{Titik Koordinat 107,5 BT; 4,5 LS}

Pada titik koordinat keempat 107,5 BT; 4,5 LS Pelatihan juga dilakukan berulang hingga mencapai MSE yang ditentukan yakni sebesar 0,17 . Dari proses pelatihan didapatkan koefisien korelasi sebesar 0,91 hal ini menunjukkan hubungan yang sangat tinggi antara data output dan data target.

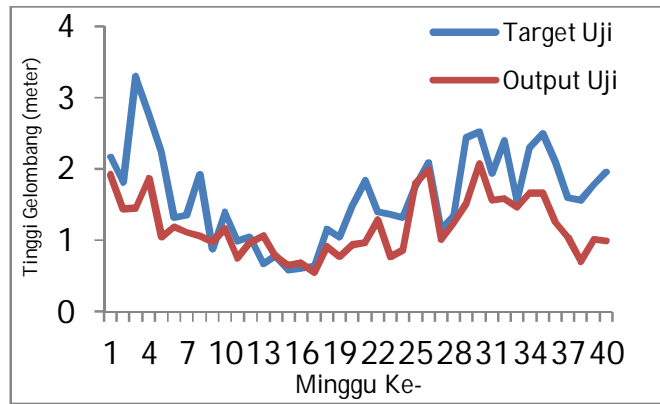

Gambar 9. Hasil pengujian data uji

Perbandingan pola antara data target dan data uji dalam proses pengujian terlihat sangat mendekati, sebagaimana terlihat pada Gambar 9, serta didapatkan koefisien korelasi sebesar 0,74 atau dalam kategori yang tinggi untuk diteruskan ke dalam proses prediksi

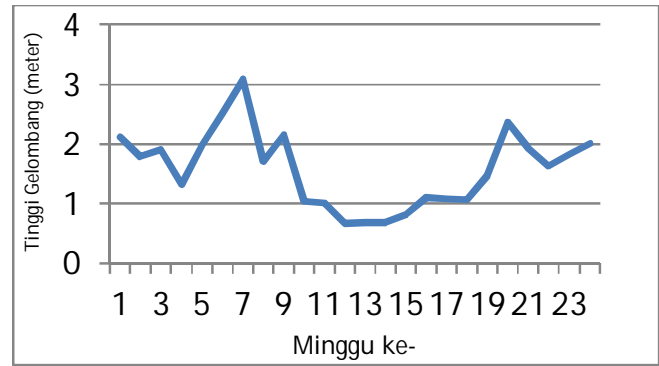

Gambar 10. Prediksi tinggi gelombang

Terlihat pada Gambar 10, puncak tertinggi ketinggian gelombang maksimum terjadi pada minggu ke-3 Desember 2014 dan terendah terjadi pada minggu ke-4 Januari 2015.

\section{Titik Koordinat 107,5 BT; 5,5 LS}

Pada titik koordinat kelima 107,5 BT; 5,5 LS pelatihan juga dilakukan berulang hingga mencapai MSE yang ditentukan yakni sebesar 0,17 . Pada proses pelatihan didapatkan koefisien korelasi sebesar 0,92 yang menunjukkan hubungan yang sangat tinggi antara data output dan data target.

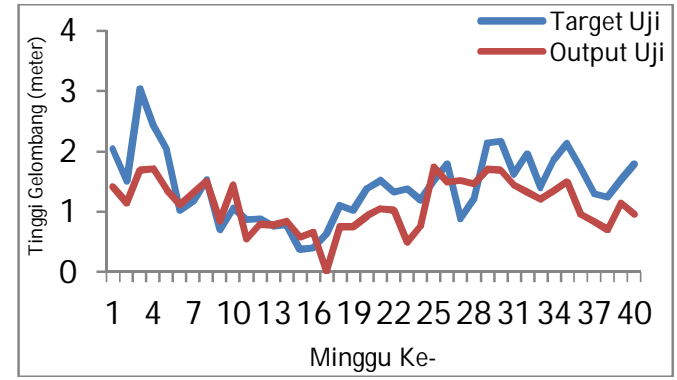

Gambar 11. Hasil Pengujian data uji

Perbandingan antara data keluaran dengan data target dalam proses pengujian menunjukkan pola yang sangat mendekati 
seperti yang terlihat pada Gambar 11 dan koefisien korelasi yang dihasilkan sebesar 0,70 atau dalam kategori yang tinggi untuk diteruskan ke dalam proses prediksi

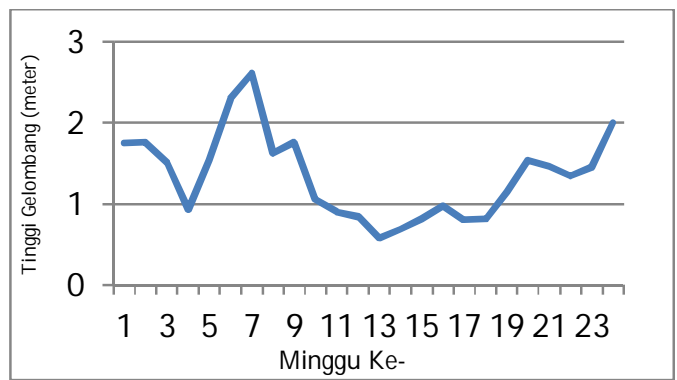

Gambar 12. Prediksi tinggi gelombang tahun 2014

Dari hasil prediksi sebagaimana terlihat pada Gambar 12, didapatkan puncak tertinggi ketinggian gelombang maksimum terjadi pada minggu ke-3 Desember 2014 dan terendah terjadi pada minggu pertama Februari 2015.

\section{Hasil Prediksi Ketinggian Gelombang}

Hasil Pengolahan data ketinggian gelombang maksimum dari tahun 2005 hingga 2014 menggunakan metode Jaringan Syaraf Tiruan Propagasi Balik, didapatkan prediksi ketinggian gelombang pada lima titik penelitian (Perairan Laut Jawa bagian Barat sebelah Utara Jakarta) seperti pada Tabel 3.
Tabel 3. Prediksi ketinggian gelombang Perairan Laut Jawa bagian Barat sebelah Utara Jakarta

\begin{tabular}{|c|c|c|c|c|c|c|c|}
\hline \multirow{2}{*}{ No } & \multirow{2}{*}{ BULAN } & \multirow{2}{*}{$\begin{array}{l}\mathrm{M} \\
\mathrm{I} \\
\mathrm{N} \\
\mathrm{G} \\
\mathrm{G} \\
\mathrm{U} \\
\mathrm{K} \\
\mathrm{E}-\end{array}$} & \multicolumn{5}{|c|}{$\begin{array}{l}\text { TINGGI GELOMBANG (METER) } \\
\text { PADA KOORDINAT }\end{array}$} \\
\hline & & & $\begin{array}{c}106,5 \\
\text { BT } \\
4,5 \text { LS }\end{array}$ & $\begin{array}{c}106,5 \\
\text { BT } \\
5,5 \text { LS }\end{array}$ & $\begin{array}{c}107 \\
\text { BT } \\
5,0 \mathrm{LS}\end{array}$ & $\begin{array}{c}107,5 \\
\text { BT } \\
4,5 \mathrm{LS}\end{array}$ & $\begin{array}{c}107,5 \\
\text { BT } \\
5,5 \mathrm{LS}\end{array}$ \\
\hline 1 & \multirow{4}{*}{$\begin{array}{c}\text { NO } \\
\text { VEM } \\
\text { BER } \\
2014\end{array}$} & 1 & 1,33 & 1,7 & 1,92 & 2,11 & 1,75 \\
\hline 2 & & 2 & 1,34 & 1,26 & 1,57 & 1,79 & 1,76 \\
\hline 3 & & 3 & 1,27 & 1,14 & 1,42 & 1,91 & 1,51 \\
\hline 4 & & 4 & 1,31 & 1,24 & 1,17 & 1,33 & 0,93 \\
\hline 5 & \multirow{4}{*}{$\begin{array}{c}\text { DE } \\
\text { SEM } \\
\text { BER } \\
2014\end{array}$} & 1 & 1,88 & 1,4 & 2 & 1,98 & 1,54 \\
\hline 6 & & 2 & 2,15 & 1,64 & 2,42 & 2,51 & 2,3 \\
\hline 7 & & 3 & 2,32 & 2,08 & 2,83 & 3,08 & 2,61 \\
\hline 8 & & 4 & 1,45 & 1,26 & 1,63 & 1,71 & 1,63 \\
\hline 9 & \multirow{4}{*}{$\begin{array}{c}\text { JA } \\
\text { NUA } \\
\text { RI } \\
2015\end{array}$} & 1 & 1,64 & 1,32 & 1,87 & 2,16 & 1,76 \\
\hline 10 & & 2 & 0,97 & 0,98 & 1,26 & 1,04 & 1,06 \\
\hline 11 & & 3 & 0,81 & 0,7 & 0,97 & 1,01 & 0,9 \\
\hline 12 & & 4 & 0,74 & 0,76 & 0,77 & 0,67 & 0,84 \\
\hline 13 & \multirow{4}{*}{$\begin{array}{c}\text { FE } \\
\text { BRU } \\
\text { ARI } \\
2015\end{array}$} & 1 & 0,63 & 0,62 & 0,68 & 0,68 & 0,58 \\
\hline 14 & & 2 & 0,64 & 0,55 & 0,7 & 0,68 & 0,69 \\
\hline 15 & & 3 & 0,64 & 0,63 & 0,71 & 0,81 & 0,81 \\
\hline 16 & & 4 & 0,77 & 0,84 & 0,83 & 1,11 & 0,98 \\
\hline 17 & \multirow{4}{*}{$\begin{array}{l}\text { MARET } \\
2015\end{array}$} & 1 & 0,93 & 0,74 & 0,9 & 1,08 & 0,8 \\
\hline 18 & & 2 & 0,89 & 0,75 & 0,73 & 1,07 & 0,81 \\
\hline 19 & & 3 & 1,09 & 1 & 1,16 & 1,47 & 1,15 \\
\hline 20 & & 4 & 1,83 & 1,3 & 1,88 & 2,37 & 1,54 \\
\hline 21 & \multirow{4}{*}{$\begin{array}{l}\text { APRIL } \\
2015\end{array}$} & 1 & 1,56 & 1,24 & 1,65 & 1,93 & 1,46 \\
\hline 22 & & 2 & 1,18 & 1,23 & 1,44 & 1,63 & 1,35 \\
\hline 23 & & 3 & 1,39 & 1,27 & 1,23 & 1,83 & 1,45 \\
\hline 24 & & 4 & 1,91 & 1,54 & 2,09 & 2,01 & 2,0 \\
\hline
\end{tabular}

Berdasarkan Tabel 3, dapat dilihat nilai prediksi untuk 24 minggu dari Bulan November 2014 hingga April 2015 dengan tinggi gelombang maksimum tertinggi (yang diberi warna kuning) terjadi pada minggu pertama bulan November 2014, bulan Desember 2014 dari minggu pertama hingga keempat, minggu pertama Januari 2015, minggu keempat bulan Maret 2015 dan minggu keempat bulan April 2015.

\section{Pembahasan Prediksi Tinggi gelombang}

Dari hasil prediksi Jaringan syaraf tiruan propagasi balik, kemudian dilakukan pemetaan dengan pembahasan sebagai berikut:

1. Bulan November 2014

Pada bulan November 2014 puncak tinggi gelombang daerah penlitian terjadi pada minggu pertama dan kedua, khususnya 
terjadi disebelah Timur daerah penelitian sebagaimana terlihat pada Tabel 3.

2. Bulan Desember 2014

Pada Bulan Desember 2014 puncak tinggi gelombang daerah penelitian terjadi pada minggu kedua dan ketiga, khususnya terjadi di sebelah Utara dan Timur Laut daerah penelitian sebagaimana terlihat pada Tabel 3.

3. Bulan Januari 2015

Pada bulan Januari 2015 puncak tinggi gelombang terjadi pada minggu pertama, khususnya terjadi di sebelah Timur Laut daerah penelitian sebagaimana terlihat pada Tabel 3.

4. Bulan Februari 2015

Pada bulan Februari 2015 puncak tinggi gelombang terjadi pada minggu keempat, khususnya terjadi di sebelah Timur Laut daerah penelitian sebagaimana terlihat pada Tabel 3.

5. Bulan Maret 2015

Pada bulan Maret 2015 puncak tinggi gelombang terjadi pada minggu keempat, khususnya terjadi di sebelah Utara dan Timur Laut daerah penelitian sebagaimana terlihat pada Tabel 3.

6. Bulan April 2015

Pada bulan April 2015 puncak tinggi gelombang terjadi pada minggu keempat, khususnya terjadi di sebelah Utara, Tengah dan Timur Laut daerah penelitian sebagaimana terlihat pada Tabel 3.

\section{Kesimpulan}

Ketinggian gelombang perairan Laut Jawa bagian Barat sebelah Utara Jakarta dapat diprediksi dengan menggunakan Metode Jaringan Syaraf Tiruan Propagasi Balik dimana masukan sistem dari jaringan dalam proses pelatihan adalah ketinggian gelombang pada minggu ke-1 hingga minggu ke-264, sedangkan target sistem adalah ketinggian gelombang pada minggu ke-145 hingga minggu ke-288, yang kemudian diuji dengan menggunakan 184 data ketinggian gelombang.

Dari pengolahan data-data tersebut didapatkan nilai prediksi untuk 24 minggu dari November 2014 hingga April 2015 dengan gelombang maksimum tertinggi terjadi pada minggu pertama bulan Nopember 2014, bulan Desember 2014 dari minggu pertama hingga keempat, minggu pertama Januari 2015, minggu keempat bulan Maret 2015 dan minggu keempat bulan April 2015.

\section{Daftar Pustaka}

Agustin, M. 2012. Penggunaan Jaringan Syaraf Tiruan Propagasi Balik Dalam Penerimaan Mahasiswa Baru Pada Jurusan Teknik Komputer Di Politeknik Negeri Sriwijaya. Skripsi. Tidak dipublikasikan. Semarang: Universitas Diponegoro

Bekalani, I. 2013. Prediksi Tinggi Significant Gelombang Laut Di Sebagian Wilayah Perairan Indonesia Menggunakan Jaringan Syaraf Tiruan Propagasi Balik. Skripsi. Tidak dipublikasikan. Pontianak: Universitas Tanjungpura

Dahuri, R. 2004. Pengelolaan Sumber Daya Wilayah Pesisir dan Lautan Secara Terpadu, Edisi Revisi. Jakarta: Pradnya Paramita.

Kresnawan, A. 2009. Penerapan Model Jaringan Syaraf Tiruan Untuk Memprediksi Gangguan Cuaca Maritim di Wilayah Tanjung Perak Surabaya. Skripsi. Tidak dipublikasikan. Surabaya: ITS

Siang, J.J. 2004. Jaringan Syaraf Tiruan Dan Pemogramannya Menggunakan MATLAB. Yogyakarta: Andi

Solihati, I. 2011. Estimasi Suhu Kota Pontianak Berdasarkan Jaringan Syaraf Tiruan (JST). Skripsi. Tidak dipublikasikan. Pontianak: Universitas Tanjungpura

Sugiyono. 2008. Metode Penelitian Kunatitatif Kualitatif dan R\&D. Bandung: Alfabeta.

www.maritim.bmkg.go.id diakses pada tanggal 1 Maret 2015 